\title{
+ \\ Risk of Increasing Income Inequality and Poverty: Analysis by Income Source
}

\author{
Elena Makarenko ${ }^{1}$, Lyudmila Nivorozhkina ${ }^{2, *} \mathbb{C}$, Alexandra Tregubova ${ }^{2} \mathbb{D}$, Tatiana Toropova ${ }^{2}$ \\ and Elmira Nazarova ${ }^{3}$
}

1 Department of Accounting, Rostov State University of Economics, 344000 Rostov-on-Don, Russia; rector@rsue.ru

2 Department of Statistics, Econometrics and Risk Assessment, Rostov State University of Economics, 344000 Rostov-on-Don, Russia; alexandra_a_t@mail.ru (A.T.); toropova@rsue.ru (T.T.)

3 Graduate School of Service and Trade, Institute of Industrial Management, Economics and Trade, Peter the Great St. Petersburg Polytechnic University, 195251 St. Petersburg, Russia; nazarova_ea@spbstu.ru

* Correspondence: lin45@mail.ru

check for updates

Citation: Makarenko, E.; Nivorozhkina, L.; Tregubova, A.; Toropova, T.; Nazarova, E. Risk of Increasing Income Inequality and Poverty: Analysis by Income Source. Sustainability 2022, 14, 1610. https:/ / doi.org/10.3390/su14031610

Academic Editor: Ermanno C. Tortia

Received: 26 November 2021

Accepted: 24 January 2022

Published: 29 January 2022

Publisher's Note: MDPI stays neutral with regard to jurisdictional claims in published maps and institutional affiliations.

Copyright: (C) 2022 by the authors. Licensee MDPI, Basel, Switzerland. This article is an open access article distributed under the terms and conditions of the Creative Commons Attribution (CC BY) license (https:// creativecommons.org/licenses/by/ $4.0 /)$.

\begin{abstract}
The high and persistent level of income inequality limits the opportunities for economic growth and contributes to the persistence of a high poverty rate in Russia. Reducing inequality is integral to achieving the Sustainable Development Goals (SDG-10); thus, greater focus is needed to reduce income inequality. We assess income inequality based on a representative income and expenditure data collected at the micro level to determine the risk of increasing inequality and poverty in the context of specific socio-demographic groups and income sources. We look at the contribution of various household income sources to total income inequality, taking into account the differences in the weighting of income components, the unevenness of their distribution, and their correlation with the total distribution of income. The main data source is the project "The Russia Longitudinal Monitoring Survey-Higher School of Economics" (RLMS-HSE) for 2000-2018. Calculation of the elasticity of the Gini index by sources of total income for poor and non-poor households revealed their multidirectional impact on overall inequality. We show that social transfers in poor households do not help to reduce inequality. This indicates the need for closer attention to this phenomenon when making policy decisions connected with social policy. Moreover, the "hidden incomes" appear to be a factor reducing inequality for poor households within the framework of the accepted definitions and the formed sample of households.
\end{abstract}

Keywords: digital economy; digital ecosystem risks; income inequality; components of income; hidden income; poverty; Gini index decomposition

\section{Introduction}

Growing inequality has negative economic, social, and political consequences. The Sustainable Development Goals (The 2030 Agenda for Sustainable Development [1], adopted by all United Nations Member States in 2015) include the reduction of inequality and the end of poverty in all forms. The evaluation and analysis of inequality and poverty phenomena arising from the distribution of incomes has been widely covered in the existing literature. For an overview of the research on economic inequality in the context of the Sustainable Development Goals, see Kanbur (2021) [2]. Modern analysis of inequality began with the contributions of Pareto (1898) [3] and Gini (1912) [4]. Later, Dalton (1920) [5] formalized axioms of income inequality measurement. Kuznets (1955) [6] offered the "Kuznets hypothesis" on an inverse-U relationship between income inequality and per capita income, but Piketty and Saez (2003) [7] and Piketty (2014) [8] revealed a sharply rising trend in inequality in the US from the mid-1980s onwards. The literature on inequality and poverty and on income distribution flourished in 1960s and 1970s. The leaders here are the works of Atkinson (1970) [9] and Sen (1973) [10], (1976) [11] that defined the normative 
foundations of inequality and poverty measurement. The rising interest in academic and in policy circles on questions of inequality reflected The World Inequality Report (Alvaredo et al., 2018 [12]). At the macro level, inequality is traditionally measured by the Gini index, which, given the consistency of the definitions of income and the periods of their measurement, makes possible comparing them over time, between countries, regions, etc. In the context of estimating income inequality, numerous studies have been published by statistical agencies and international organizations. Russia is among the countries with a high inequality rate. The risks of increases or decreases in inequality and poverty at the macro level are discussed in the context of macroeconomic indicators, such as GDP, the level of socio-economic development of countries or territories, global climate change, and armed conflicts (World Bank Report 2020 [13]), which generate many discussions on the fair distribution of income in society (Milanovic 2011 [14], Kapelyushnikov 2019 [15], Deaton 2021 [16]).

However, measuring income inequality is not bounded to macroeconomic measurements. Improving methods of collection, accumulation, and exchange of information on the incomes and expenditures of the population, based on representative microdata of different countries (Sources available online: https:/ / www.lisdatacenter.org/our-data/ lis-database/, https:/ / cnef.ehe.osu.edu/, https://www.hse.ru/rlms/spss (accessed on 8 September 2020)), makes possible the use of methods of econometric modeling to obtain estimates of income inequality consistent with macroeconomic indicators. This would allow for identifying the factors underlying income inequality and poverty, as well as assessing and predicting the risks of their growth in the context of specific socio-demographic groups and sources of income (Ibragimova and Franz 2019 [17], Brewer and Wren-Lewis 2016 [18], Cowell and Fiorio 2011 [19], Fields 2003 [20]).

Collecting data on the incomes of the population is one of the most difficult procedures in organizing surveys and often challenges the quality of the results obtained. The accelerating process of digitalization of all aspects of life and the improvement of the methodology for treating big data in the coming years are fundamentally changing the ways of obtaining data on all aspects of human life. The accumulated potential of statistical and econometric methods for processing and analyzing data from surveys of the population makes it possible to assess the process of inequality formation in the context of various income groups in the population. In this context, we can also reveal the contribution of various components of income to the formation of general inequality, especially incomes hidden from official accounting, which are largely the result of the informal activity of the population. This part of hidden income, in contrast to criminal income, could be identified through population surveys. This approach creates the basis for improving the social policy of the state and allows for the development of targeted measures that eliminate the risks of increasing inequality and poverty in society.

The purpose of this study is to identify the role of the components of available resources in Russian households, including hidden ones, in the formation of inequality for the period from 2000 to 2017, as well as to assess the risk of growth or decreases in inequality by components of available resources among poor and non-poor households that leads to achieving the Sustainable Development Goals.

Previous research has studied the dynamics and factors that affect income inequality among Russian households. Most of the research covers periods starting from the early 1990s because of limitations in the official Soviet statistics (Atkinson and Micklewright 1992 [21]). Early studies analyzed the development of households' incomes during the 1990s and identified various factors that affected inequality (Milanovic 1998 [22], Commander et al., 1999 [23] and Dang et al., 2020 [24]). Several papers looked at the impact of income components on the levels of inequality in Russia (Lisina and Van Kerm 2019 [25], Gustafsson et al., 2011 [26]). Gustafsson et al. (2011) [26] uses data for 2003 and studies the contribution of various income components to the overall inequality in Russia and China. Gustafsson et al. (2011) [26] considers the following main income components: income from wages and entrepreneurial activities, farming income, public 
and private transfers and imputed rents and housing subsidies. This study extends the results of Gustafsson et al. (2011) [26] for Russia in that it considers an additional income component that was previously not discussed in the literature: hidden incomes. The impact of hidden incomes on inequality may be potentially large. Previous studies by Murashov and Ratnikova (2016) [27] alongside figures of the Russian Statistical Agency confirm the relative importance of hidden incomes in the overall income of Russian households. In addition, this study looks at the above-mentioned effects in the dynamic perspective by considering an unusually long period of observations 2002-2017.

\section{Data and Methodology}

The conditions to be met by measures of inequality that allow them to be decomposed in terms of shares of total inequality explained by different sources of income or by different characteristics of households (individuals) were formulated by Shorrocks (1982) [28], (1984) [29]. It was proved that measures allowing such a decomposition should be symmetric, continuous, and equal to zero if all incomes are equal. The most widely known measure of inequality is the Gini index, used to measure inequality in the distribution of income, consumption, and other indicators of well-being, and it meets the above conditions for its decomposition by source of income (Stark et al., 1986 [30]).

The total household income is generated from various sources, such as income from wages, property, public and private transfers, and other components. Each of the components of total income is characterized by a share (weight) in total income, the degree of uniformity of distribution relative to total income, and correlation with total income. Based on these characteristics, Lerman and Yitzhaki 1985 [31] developed a Gini decomposition method to reveal the relative importance of the contribution of various components of total income to total inequality. According to the author's methodology, the Gini index is:

$$
G=\sum_{k=1}^{K} S_{k} G_{k} R_{k}
$$

where $G_{k}$ is the Gini index for income $i$ from source $k, S_{k}$ is the share of total income from source $k, R_{k}$ is the Gini correlation between income from source $k$ and total income. Hence, $S_{k} G_{k} R_{k}$ is the bare contribution of the source of income $k$ to inequality in total income. If a source of income is unevenly distributed and disproportionately redistributed to those at the top of the income distribution $\left(R_{k}\right.$ is positive and large), its contribution to inequality will be positive. If it is unevenly distributed, but mainly among poor households (individuals), then this source of income could have a balancing effect (Nivorozhkina 2016 [32]).

Suppose $\eta_{k}=G_{k} R_{k} / G$ is the Gini income elasticity for the source $k$, then the marginal change in the total income for the $k$ source in relation to the Gini index calculated for the total income is:

$$
\frac{\partial G / \partial e}{G}=\frac{S_{k} G_{k} R_{k}}{G}-S_{k}=S_{k}\left(\eta_{k}-1\right)
$$

Thus, decomposition of the Gini index allows for assessing the effect of marginal changes in the source of income on overall inequality (Lopes-Feldman 2006 [33]).

The next highlight of the analysis undertaken is the connection between inequality and poverty. Income inequality is a situation in a society in which income is unevenly distributed between different people and households. People with incomes below a certain threshold accepted as the minimum standard in society are considered poor. This is just one of several definitions of poverty, but it is closely related to inequality and allows them to be analyzed in a single context.

During the study period from 2000 to 2017, there was a synchronous decrease in inequality and poverty indicators, reflecting their sensitivity to crisis processes in Russian society. Since the cumulative distributions of poor and non-poor do not intersect, it is possible to de-compose the Gini index into the following: inequality among the poor and among the non-poor, and intergroup inequality. This approach makes possible analyzing 
relative poverty and inequality, and additionally obtaining information to assess the risks of inequality and poverty and trends in their formation.

We divide the initial data into two groups:

- Poor, with incomes $y \leq Z$ (Z-poverty threshold),

- Non-poor, with incomes $y>Z$.

Then the Gini index for total income G:

$$
G=S_{p} G_{p} P_{p}+S_{r} G_{r} P_{r}+G_{b}
$$

where $p$-group of poor, $r$-group of non-poor, $P$ - the share of the group in the total

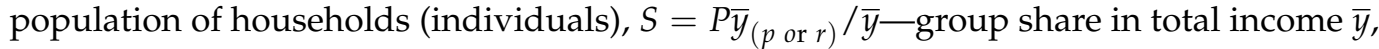
$G_{b}$-intergroup inequality. Note that $S_{r}=1-S_{p}, P_{r}=1-P_{p}$. Likewise, $S_{b}=P_{p}-S_{p}$ intergroup inequality equals the share of the poor in the aggregate minus their share in the income.

The relative contribution to inequality between the poor and the non-poor and the intergroup effect could be represented as a function of these contributions to the overall inequality:

$$
\begin{gathered}
w_{p}=\frac{S_{p} G_{p} P_{p}}{G} ; w_{r}=\frac{S_{r} G_{r} P_{r}}{G} ; w_{b}=\frac{G_{b}}{G} \\
w_{p}+w_{r}+w_{b}=1
\end{gathered}
$$

Gini total income elasticity according to Yitzhaki (2002) [34]:

$$
\eta=\frac{w_{p} S_{p}}{S} \eta_{p}+\frac{w_{r} S_{r}}{S} \eta_{r}+w_{b} \eta_{b}
$$

The last equation represents the total Gini income elasticity as a weighted sum of the intra and inter-group elasticities: e.g., if $\eta_{p}>1$, then the increase of the $k$ income source increases the Gini index (income inequality) among the poor (Nivorozhkina et al., 2007 [35]).

The source of the initial data for assessing and analyzing the risk of rising income inequality and the relative poverty of Russian households is the project "The Russia Longitudinal Monitoring Survey-Higher School of Economics" (RLMS-HSE) [36] for 2000-2017, which represent common categories of Russia's population. RLMS-HSE is a series of nationally representative surveys designed to monitor the effects of Russian reforms on the health and economic welfare of households and individuals in the Russian Federation. Thus, the following categories in the survey are not represented: institutional population; ones without a fixed abode/vagrants; very rich ones). The key advantage of the RLMS-HSE study is a unified methodology for generating indicators of household income and expenditure throughout the entire period.

Households are the subjects of the research. The original sample size ranged from 4005 in 2000 to 7112 households in 2017. As an indicator of household welfare, an indicator of monthly disposable resources per capita (hereinafter referred to as income) was formed, which includes, in addition to monetary income, an estimate of natural consumption from various sources, as well as spent loans and savings and an estimate of hidden income. Households with no income source indicated were excluded from the analysis.

The authors' approach to calculating household disposable resources was as follows: (Methodology for calculating the main categories of household income and expenditure is available on request via: lin45@mail.ru) 'Disposable resources' $=$ households' income from wages (including the monetary value of payments in kind) + social transfers (pensions, scholarships, allowances, etc.) + private transfers (help from relatives, charitable organizations, etc.) + income from the sale of household plots + other income (debt repayments, insurance payments, sale of personal property, rental of property, capital investment in the form of interest on deposits, shares and other securities) + loans and spent savings + hidden income. 
Loans and spent savings accumulate funds that remained in the household budget in previous periods after the necessary expenses and taxes. This residual income is spent at the sole discretion of the consumer. Part of these funds are to be spent in the next period, while the other part may be set aside in the form of savings. In addition, the spent savings and loans include funds spent on major purchases: real estate, cars, etc., and in this case significantly exceed the monthly budget of the household. Nevertheless, it could be found as a part of available resources of the household in the analyzed period and it should be taken into account.

The methodology and empirical assessment of the hidden income component of Russians, based on the model of Pissarides and Weber (1989) [37], is highlighted in the studies of Nivorozhkina and Arzhenovskiy (2020) [38] and Murashov and Ratnikova (2017) [39]. To highlight the components of hidden income, the original annual household data, from 2000 to 2017 inclusive, were transformed into panels for three consecutive years, and all subsequent calculations were carried out on the data of the final year of the panel. The sample size was 3175 for the 2000-2002 panel, 3764 for the 2003-2005 panel, 4276 for the 2006-2008 panel, 4295 for the 2009-2011 panel, 5364 for the 2012-2014 panel, and 5860 for the 2015-2017 panel. Households with hidden income were considered to be those in which current expenditures exceeded disposable resources by at least $10 \%$ for three consecutive periods.

The concept presented leaves for analysis only those households in which the hidden income component is stable. However, as noted earlier, the sample does not include either the very poor or the very rich; those who derive such income from time to time could also be eliminated from observation. But the discussion about the need to validate hidden income concerns mainly those groups of the population that receive them constantly but do not declare them to the authorities. How unevenly distributed is this income component and how high is the risk that it increases income inequality? The answers are undoubtedly important for the formation of a fair policy in the field of the income of the population.

\section{Results}

\subsection{Decomposition of General Inequality by Income Sources}

The results of the decomposition of general inequality by sources of income are presented in Table 1.

The key part of household income is wages, which accounted for more than half of the family's budget. Over the entire period, the level of inequality in the distribution of this component of disposable resources, measured by the Gini index, gradually decreased from 0.61 to 0.55 . The contribution of wages to total inequality was also slightly more than half. A fairly strong correlation with total income gradually decreased from 0.76 to 0.68 over time. The dynamics of indicators describing inequality in the distribution of this component were affected by the 2008 crisis, when the Russian government took a number of significant measures to support employment. The consequence of these measures was an increase in the share of wages in total income and in general inequality, as well as the strongest correlation of this component with the distribution function of total income. The increase in the impact of a $1 \%$ change in wages on overall inequality this year also indicated that economic crises triggered a rise in the risk of wages becoming a factor in increasing inequality.

The share of social transfers was $20-29 \%$ of the monthly family budget. A noticeable increase in this share in 2011 was caused by valorization of pensions, and in 2017 it was caused by significant indexation of all social payments made by the state. These measures have resulted in an increase in the share of social transfers in overall inequality. Throughout the entire period, the Gini index for this component of income was also quite high (0.6), and the correlation with the distribution function of total income was significantly lower than for wages but increased from 0.16 to 0.22 . In the crisis year of 2008, the correlation of social transfers with the general distribution of incomes decreased markedly, as did the 
share of this component in total income. Therefore, a one percent increase in income from this source was a factor in reducing overall inequality.

Table 1. Decomposition of general inequality by sources of income according to Lerman and Yitzhaki.

\begin{tabular}{|c|c|c|c|c|c|c|c|c|}
\hline Index & Year & $\begin{array}{c}\text { Salaries and } \\
\text { Wages in Kind }\end{array}$ & $\begin{array}{c}\text { Social } \\
\text { Transfers }\end{array}$ & Transfers & $\begin{array}{l}\text { Other } \\
\text { Income }\end{array}$ & Loans & $\begin{array}{c}\text { Household } \\
\text { Farms' Income }\end{array}$ & $\begin{array}{l}\text { Hidden } \\
\text { Income }\end{array}$ \\
\hline \multirow{6}{*}{$\begin{array}{c}\text { Impact of } 1 \% \\
\text { change in source of } \\
\text { income on overall } \\
\text { inequality }\end{array}$} & 2002 & 0.022 & -0.17 & 0.005 & 0.019 & 0.104 & 0.008 & 0.012 \\
\hline & 2005 & 0.019 & -0.174 & 0.004 & 0.020 & 0.131 & 0.006 & -0.017 \\
\hline & 2008 & 0.038 & -0.185 & 0.005 & 0.024 & 0.116 & 0.008 & -0.004 \\
\hline & 2011 & -0.004 & -0.161 & 0.004 & 0.019 & 0.136 & 0.007 & -0.001 \\
\hline & 2014 & 0.018 & -0.165 & 0.009 & 0.020 & 0.121 & 0.003 & -0.005 \\
\hline & 2017 & -0.005 & -0.179 & -0.002 & 0.050 & 0.133 & 0.004 & -0.001 \\
\hline \multirow{6}{*}{$\begin{array}{l}\text { Gini index for } \\
\text { income } \\
\text { component } G_{k}\end{array}$} & 2002 & 0.614 & 0.607 & 0.904 & 0.974 & 0.95 & 0.976 & 0.911 \\
\hline & 2005 & 0.579 & 0.622 & 0.892 & 0.980 & 0.953 & 0.975 & 0.938 \\
\hline & 2008 & 0.552 & 0.603 & 0.907 & 0.988 & 0.962 & 0.994 & 0.950 \\
\hline & 2011 & 0.543 & 0.606 & 0.905 & 0.985 & 0.966 & 0.981 & 0.964 \\
\hline & 2014 & 0.540 & 0.601 & 0.904 & 0.985 & 0.968 & 0.479 & 0.924 \\
\hline & 2017 & 0.548 & 0.588 & 0.901 & 0.991 & 0.969 & 0.981 & 0.967 \\
\hline \multirow{6}{*}{$\begin{array}{l}\text { Correlation of the } \\
\text { component of } \\
\text { income with the } \\
\text { distribution } \\
\text { function of total } \\
\text { income } R_{k}\end{array}$} & 2002 & 0.758 & 0.156 & 0.532 & 0.766 & 0.843 & 0.607 & 0.57 \\
\hline & 2005 & 0.762 & 0.138 & 0.505 & 0.764 & 0.872 & 0.521 & 0.266 \\
\hline & 2008 & 0.809 & 0.043 & 0.499 & 0.849 & 0.873 & 0.568 & 0.298 \\
\hline & 2011 & 0.714 & 0.250 & 0.469 & 0.750 & 0.887 & 0.552 & 0.370 \\
\hline & 2014 & 0.713 & 0.239 & 0.483 & 0.778 & 0.878 & 0.479 & 0.221 \\
\hline & 2017 & 0.679 & 0.238 & 0.398 & 0.908 & 0.899 & 0.493 & 0.361 \\
\hline \multirow{6}{*}{$\begin{array}{l}\text { Share of income } \\
\text { component in total } \\
\text { income } S_{k}\end{array}$} & 2002 & 0.475 & 0.216 & 0.058 & 0.028 & 0.13 & 0.003 & 0.069 \\
\hline & 2005 & 0.510 & 0.218 & 0.065 & 0.026 & 0.137 & 0.030 & 0.013 \\
\hline & 2008 & 0.572 & 0.197 & 0.056 & 0.024 & 0.115 & 0.023 & 0.013 \\
\hline & 2011 & 0.524 & 0.262 & 0.051 & 0.021 & 0.114 & 0.017 & 0.011 \\
\hline & 2014 & 0.543 & 0.269 & 0.049 & 0.018 & 0.094 & 0.012 & 0.072 \\
\hline & 2017 & 0.514 & 0.285 & 0.044 & 0.035 & 0.100 & 0.013 & 0.009 \\
\hline \multirow{6}{*}{$\begin{array}{l}\text { Share of income } \\
\text { component in total } \\
\text { inequality }\end{array}$} & 2002 & 0.498 & 0.046 & 0.062 & 0.047 & 0.234 & 0.033 & 0.012 \\
\hline & 2005 & 0.529 & 0.044 & 0.069 & 0.045 & 0.268 & 0.036 & 0.008 \\
\hline & 2008 & 0.610 & 0.012 & 0.060 & 0.047 & 0.231 & 0.03 & 0.009 \\
\hline & 2011 & 0.520 & 0.102 & 0.055 & 0.040 & 0.250 & 0.023 & 0.010 \\
\hline & 2014 & 0.562 & 0.104 & 0.058 & 0.038 & 0.215 & 0.016 & 0.007 \\
\hline & 2017 & 0.509 & 0.106 & 0.042 & 0.085 & 0.233 & 0.017 & 0.008 \\
\hline
\end{tabular}

The share of income received by households from interfamily transfers and charity was within 6.5\%; however, the high inequality in their distribution (0.90) and the correlation with total income (0.40-0.53) indicated a relatively high material security of a certain parts of these households. The contribution to overall inequality of this component of income ranged from $6 \%$ to $4 \%$, and a $1 \%$ change in this source of income had very little effect on overall inequality.

The share of so-called other incomes that households received from debt repayment, insurance payments, sale of personal property, rental of property, capital investment in the form of interest on deposits, shares and other securities varied from one to three percent, and high levels of inequality and a high correlation with total income indicated that their recipients were also located predominantly at the top of the income distribution. The share of this component of income in total inequality gradually increased from $3.5 \%$ to $8.5 \%$.

A significant share of loans and spent savings provides evidence for the importance of household working capital and spending on major purchases. However, during the period reviewed, their share decreased, and the inequality in the distribution of this component in the group increased. The high correlation of this component with total income, a significant contribution to inequality (more than $20 \%$ ), as well as a significant impact on the growth of inequality indicate the extreme unevenness of its distribution. 
Income from personal subsidiary plots constituted an insignificant part of the aggregate income of households; their distribution was very uneven and did not have a noticeable effect on aggregate inequality.

Hidden income, the volume of which is imputed to households according to the results of the assessment of the Pissarides-Weber model, ranged from one to seven percent in the period analyzed. The Gini index in this group exceeded 0.9 , and the correlation with the distribution of total income was relatively small: it peaked at 0.57 in the early 2000s, and then began to decline. The contribution of this component to overall inequality did not exceed $1.2 \%$, and after 2002, a $1 \%$ increase in hidden incomes became a factor in the decrease in overall inequality. The dynamics of these indicators of inequality indicates that this component of income was grouped mainly among households with a low level of income, and its growth was not a risk factor for the growth of income inequality.

Thus, half of the contribution to total inequality, taking into account the interaction of all three components of inequality, was made by wages, a quarter by spent savings and loans, and the remaining components added another quarter.

Risks of rising inequality most accurately reflect the elasticity values for each component of disposable resources. Thus, the effect of a $1 \%$ change in the source of income on general inequality revealed that an increase in income from wages increased inequality, except for 2011 and 2017, when the 1\% increase in this component was reduced by Gini by $0.004 \%$ and $0.005 \%$, respectively. Loans and spent savings had the greatest impact on the growth of inequality: a 1 percent increase in this component of income led to an increase in the Gini index from $0.104 \%$ in 2002 to $0.133 \%$ in 2017 . As might be expected, an increase in social transfers led to a decrease in inequality. Latent incomes have become another factor in reducing inequality, despite the significant unevenness of their distribution.

\subsection{Risk Factors for Rising Inequality among Poor and Non-Poor Households}

The analysis of inequality confirmed that its dynamics are driven by the weight of the income component in total income, the unevenness of its distribution, and the correlation with the general distribution of income, and that these differences are determined by the fact that different components of income prevail in the upper and lower positions of the distribution of total household income. Therefore, one can assume their different relevance in the formation of inequality among poor and non-poor households. To test this hypothesis, we grouped households according to the level of relative poverty. Poor households were those whose available resources per capita were below the poverty threshold, which is $50 \%$ of the median available resources per capita of households, and the Gini index was decomposed into two groups (Table 2).

In the panel of 2000-2002, the share of the poor was $15.9 \%$, which was an echo of the 1990s crisis. Later, this indicator gradually decreased to $9.9 \%$ in 2017. The second row of the table presents the average per capita available resources in each group. The average per capita resources of non-poor households exceeded the incomes of the poor by 4-5 times. The third row represents the Gini index, which decreased from 0.45 to 0.37 . Inequality among the poor during the study period decreased from 0.23 to 0.16 , among the rich from 0.40 to 0.34 , and intergroup inequality from 0.12 to 0.07 , respectively.

As noted above, the impact of social policy measures on inequality can be represented as a function of all effects of each of the components of inequality weighted by their share in total inequality. The share of each component in the Gini index was defined as $w_{p}$ for the poor, $w_{r}$ for the non-poor, and $w_{b}$ between groups. The fourth row of Table 2 indicates the contribution of the poor, non-poor, and the Gini between-group inequality gap. It was not the poor households that made the major contribution to inequality. It is important to note that the contribution of inequality among the poor to the Gini index did not exceed $0.3 \%$, that is, the contribution of inequality among the poor to total inequality was negligible. However, this does not mean that poverty does not affect overall inequality. Its impact is expressed in terms of weight attributed to inequality between groups, ranging from $27 \%$ to $20 \%$. 
Table 2. Gini index components by income among poor and non-poor households.

\begin{tabular}{|c|c|c|c|c|c|c|}
\hline Year & $\begin{array}{c}\text { Poverty } \\
\text { Threshold, Rub }\end{array}$ & Index & Total Population & Poor & Non-Poor & Intergroup Inequality \\
\hline \multirow{4}{*}{2002} & \multirow{4}{*}{1062.50} & Share of households & 3175 & 0.1594 & 0.8406 & \\
\hline & & Average income, rub. & 3019.69 & 676.7 & 3463.88 & \\
\hline & & Gini index & 0.445 & 0.227 & 0.395 & 0.124 \\
\hline & & Share in total Gini & 1 & 0.0029 & 0.7194 & 0.2777 \\
\hline \multirow{4}{*}{2005} & \multirow{4}{*}{1327.56} & Share of population & 3764 & 0.1496 & 0.8504 & \\
\hline & & Average income, rub. & 5590.46 & 1297.41 & 6343.96 & \\
\hline & & Gini index & 0.425 & 0.223 & 0.377 & 0.058 \\
\hline & & Share in total Gini & 1 & 0.0003 & 0.7276 & 0.2721 \\
\hline \multirow{4}{*}{2008} & \multirow{4}{*}{3985.93} & Share of population & 4276 & 0.1399 & 0.8601 & \\
\hline & & Average income, rub. & $10,969.79$ & 2712.04 & $12,313.41$ & \\
\hline & & Gini index & 0.419 & 0.203 & 0.376 & 0.105 \\
\hline & & Share in total Gini & 1 & 0.0023 & 0.746 & 0.2516 \\
\hline \multirow{4}{*}{2011} & \multirow{4}{*}{5725.00} & Share of population & 4295 & 0.1208 & 0.8792 & \\
\hline & & Average income, rub. & $15,108.57$ & 3996.77 & $16,635.86$ & \\
\hline & & Gini index & 0.391 & 0.185 & 0.354 & 0.089 \\
\hline & & Share in total Gini & 1 & 0.0018 & 0.7708 & 0.2274 \\
\hline \multirow{4}{*}{2014} & \multirow{4}{*}{7500.00} & Share of population & 5364 & 0.1141 & 0.8859 & \\
\hline & & Average income, rub. & $19,377.66$ & 5362.31 & $21,182.67$ & \\
\hline & & Gini index & 0.372 & 0.177 & 0.337 & 0.083 \\
\hline & & Share in total Gini & 1 & 0.0017 & 0.7765 & 0.2218 \\
\hline \multirow{4}{*}{2017} & \multirow{4}{*}{8879.56} & Share of population & 5860 & 0.0997 & 0.9003 & \\
\hline & & Average income, rub. & $23,087.37$ & 6481.32 & $24,925.49$ & \\
\hline & & Gini index & 0.374 & 0.16 & 0.3454 & 0.071 \\
\hline & & Share in total Gini & 1 & 0.0012 & 0.8073 & 0.1915 \\
\hline
\end{tabular}

Knowing the share of each component of income, we could estimate the risk of inequality for each component of inequality. The parameter reflecting this effect is the income elasticity of the Gini index. Decomposition of income elasticities among the poor, the non-poor, and between them all highlights the effect of different components of income on inequality among the poor, the rich, and between them, and thereby evaluates the differences in the risks of increasing inequality for these groups. (A table with calculations of elasticities for poor, non-poor, and intergroup components of inequality, as well as standard errors obtained by the bootstrap method under the assumption of the normality of the asymptotic distribution, is available on request via: lin45@mail.ru). The main trends in the dynamics of the income elasticity of the Gini index are shown in Figure 1.

The elasticity of wages was close to one in all periods, except for 2008, when a negative value of the intergroup elasticity indicated that the measures taken by the government to mitigate the crisis resulted in reducing inequality.

Such an important component of income as social transfers was expected to be below one for the entire population of households, but when they were divided into two groups, a stable trend emerged that among the poor they were a risk factor for increasing inequality and among the non-poor for decreasing inequality.

The opposite pattern was inherent for cross-family transfers of funds from charitable organizations, where their presence reduced the risks of inequality among the poor and led to its increase among the non-poor.

The so-called other incomes steadily led to an increase in inequality among the nonpoor, and among the poor only in 2008 did they become a factor in a sharp increase in inequality, maintaining an elasticity close to one in all other periods.

Loans and spent savings were a risk factor for declining inequality in poor households and increasing inequality in non-poor households. This is quite understandable, since 
major purchases are more often made by the non-poor, and small loans are more common among the poor.

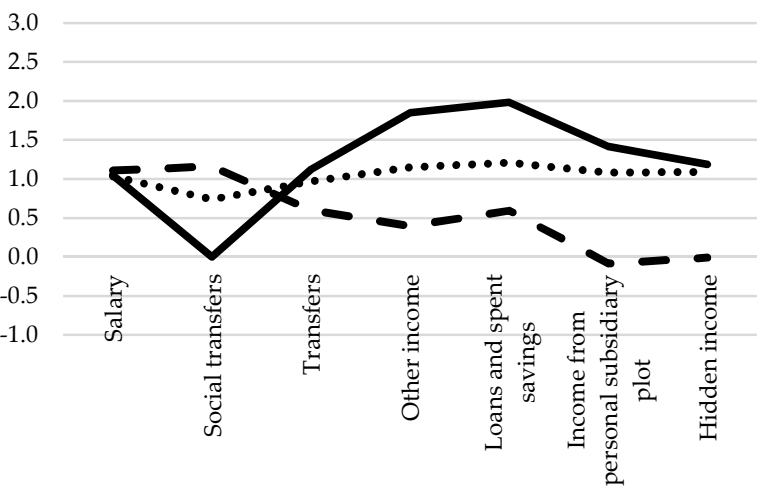

- Poor households ...... Between

(a)
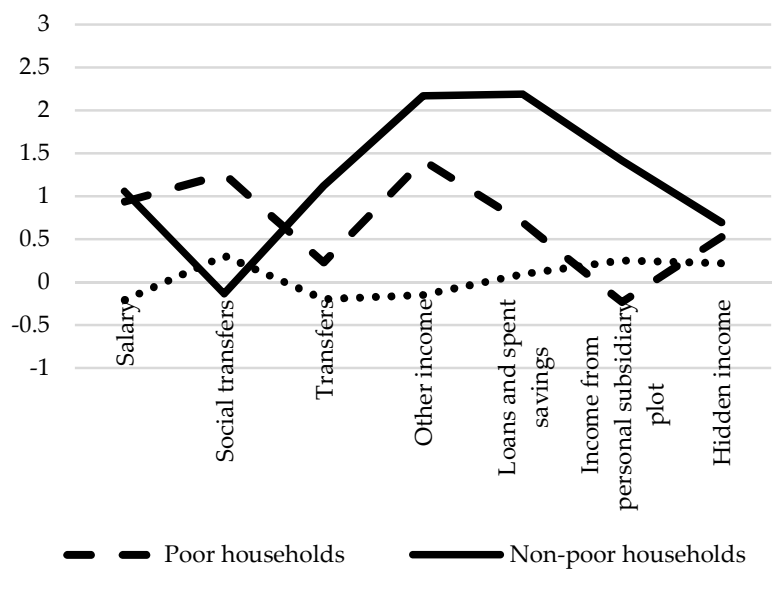

...... Between

(c)

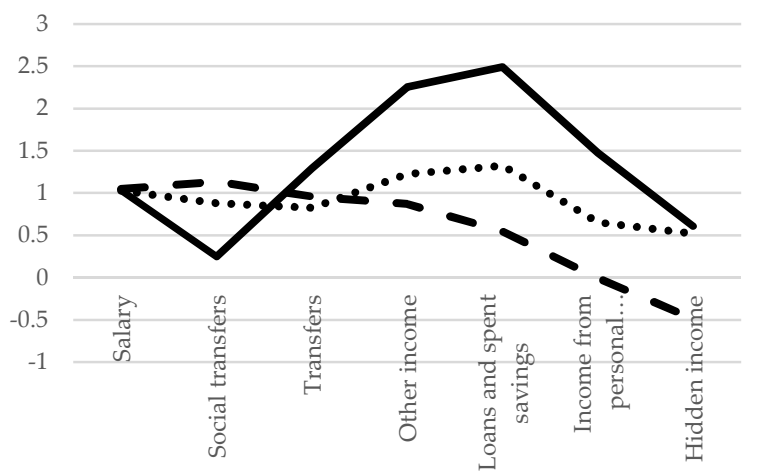

- Poor households Non-poor households

(e)

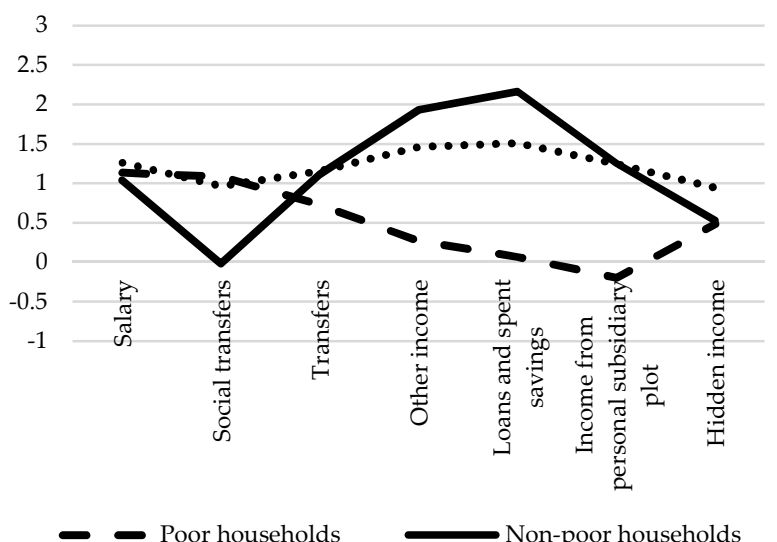

(b)

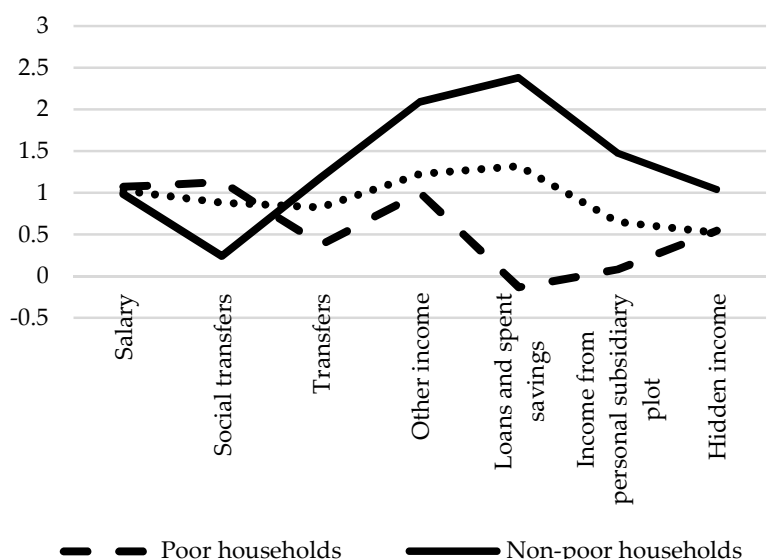

(d)

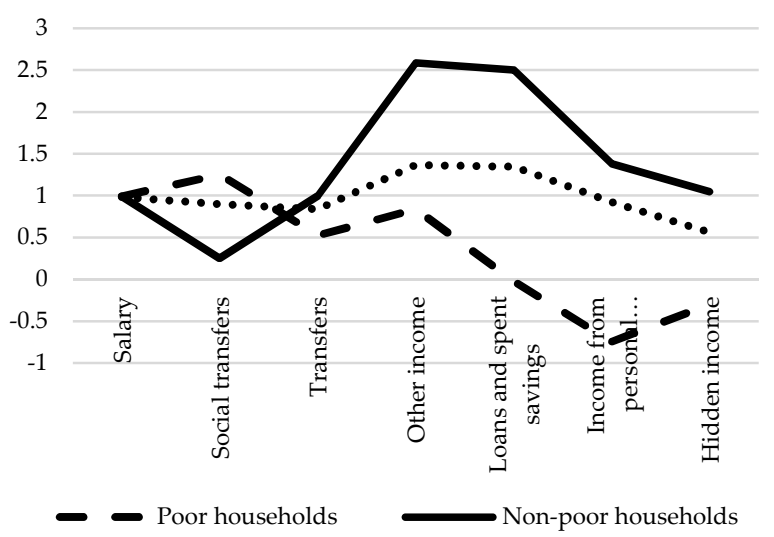

...... Between 
The values of elasticities by sources of income in the context of poor households indicated a trend that, except for wages and social transfers, the elasticity for which was close to one, all other sources of income reduced inequality, including hidden income.

As for non-poor households, here the Gini wage elasticity was close to one as well. The elasticity of social transfers, as expected, indicated that they decreased inequality, while all other sources of inequality increased. The largest increases in inequality were spotted in other incomes, loans, and spent savings. We already emphasized above that the funds saved in the previous period were spent later or saved again, but among non-poor households, this component also included major expenditures made by households from time to time.

Gini's elasticity of income from household farms was close to one or slightly higher for non-poor households, and in poor households, an increase in income from private household plots led to a decrease in inequality.

The Gini elasticity for hidden incomes among non-poor households was either close to or less than one, which indicates that among wealthy groups of the population they did not lead to an increase in inequality, although in some years they did. As for poor households, the increase in hidden incomes steadily reduced inequality.

Intergroup inequality indicated low elasticity for almost all components of income, which is evidence of a persistent gap in income inequality and its determinants between poor and non-poor households.

\section{Summary and Conclusions}

This paper contributes to the literature by presenting the first results on the decomposition of the inequality of available resources of Russian households, including an estimate of the volume of hidden income. The results are based on representative information on the incomes of Russian households covering the period from 2000 to 2017. A central contribution of the paper is an assessment of the risks of the formation of an indicator of general inequality (Gini index), taking into the account the differences in the weight of various sources of income, the degree of unevenness of their distribution, and correlations with the overall distribution of income.

Calculation of the Gini income elasticities for the components of available resources for poor and non-poor households revealed the effect of their multidirectional influence on inequality. All the components of income, except for the wages as a low elastic one, a significant elasticity of the Gini index was revealed, and, most importantly, their multidirectional effect was demonstrated for poor and non-poor households. For example, the 'other income' and 'spent savings and loans' components increased inequality in non-poor households and decreased it in the poor ones. The fact that social transfers to poor households did not help reduce inequality suggests a need for policy makers to pay closer attention to this phenomenon in the formulation of social policies.

The paper further extends the existing literature by considering the impact of 'hidden income' on inequality. The 'hidden income' component, within the framework of the accepted definition and the formed sample of households, did not have a significant effect on the risk of increasing inequality in general, and for poor households it was a factor of decline. The dynamics of hidden household incomes indicate that, for the most part, these incomes are the result of the response of households to external shocks by moving into various informal types of employment and the formation of non-standard sources of income. The results obtained confirm that hidden household incomes contribute to equalizing inequality and reducing poverty during periods of economic crises, eliminating social tension in society (Nivorozhkina 2016 [25]).

The results of the study, which revealed the multidirectionality of risk factors for the formation of inequality in terms of income components among poor and non-poor households, indicate the need to differentiate the state's social policy in the field of income generation and regulation. The modern possibilities of digitalization and treating big data allows for organizing the operational formation of data on the unique characteristics 
of individuals and households from all possible sources, including data on income and expenses. This will make possible assessing the risks of increasing poverty and household inequality in real time, thereby increasing the effectiveness of the state's social policy.

Author Contributions: Conceptualization, E.M. and L.N.; formal analysis, L.N.; methodology, L.N.; data curation, L.N., A.T. and T.T.; writing-review and editing, L.N.; supervision, E.M., L.N. and E.N. All authors have read and agreed to the published version of the manuscript.

Funding: This research was funded by RFBR, grant number 19-010-00009 “Inequality and Poverty in Post-Soviet Russia: Dynamics and Determinants with Adjustments for Hidden Incomes of Households". The research is partially funded by the Ministry of Science and Higher Education of the Russian Federation under the strategic academic leadership program 'Priority 2030' (Agreement 075-15-2021-1333 dated 30 September 2021).

Institutional Review Board Statement: Not applicable.

Informed Consent Statement: Not applicable.

Data Availability Statement: Data may be made available on request from the corresponding author.

Conflicts of Interest: The authors declare no conflict of interest.

\section{References}

1. The 2030 Agenda for Sustainable Development. 2015. Available online: https://sdgs.un.org/2030agenda (accessed on 1 October 2021).

2. Kanbur, R. Sustainable Development Goals and the Study of Economic Inequality. J. Econ. Inequal. 2020, 19, 3-11. [CrossRef]

3. Gini, C. Variabilità e mutabilità. In Memorie di Metodologica Statistica; Pizetti, E., Salvemini, T., Eds.; Libreria Eredi Virgilio Veschi: Rome, Italy, 1912.

4. Merritt, F.D. Cours d'Economie Politique. Vilfredo Pareto. J. Politi. Econ. 1898, 6, 549-552. [CrossRef]

5. Dalton, H. The Measurement of the Inequality of Incomes. Econ. J. 1920, 30, 348. [CrossRef]

6. Kuznets, S. Economic Growth and Income Inequality. Am. Econ. Rev. 1955, 45, 1-28.

7. Piketty, T. Capita in the Twenty-First Century; Harvard University Press: Cambridge, MA, USA, 2014.

8. Piketty, T.; Saez, E. Income Inequality in the United States, 1913-1998. Q. J. Econ. 2003, 118, 1-41. [CrossRef]

9. Atkinson, A.B. On the measurement of inequality. J. Econ. Theory 1970, 2, 244-263. [CrossRef]

10. Sen, A. On Economic Inequality; Oxford University Press: New York, NY, USA, 1973.

11. Sen, A. Poverty: An Ordinal Approach to Measurement. Econometrica 1976, 44, 219. [CrossRef]

12. Alvaredo, F.; Chancel, C.; Piketty, T.; Saez, E.; Zucman, G. World Inequality Report. 2018. Available online: https://wir2018.wid. world / files / download/wir2018-full-report-english.pdf (accessed on 1 October 2021).

13. World Bank Report 2020. Poverty and Shared Prosperity. In Reversals of Fortune; World Bank: Washington, DC, USA, 2020.

14. Milanovic, B. Global Inequality and the Global Inequality Extraction Ratio: The Story of the Past Two Centuries, World Bank. 2009. Available online: https:/ / openknowledge.worldbank.org/handle/10986/4237 (accessed on 1 October 2021).

15. Kapeliushnikov, R.I. Is economic inequality a universal evil? Vopr. Èkon. 2019, 4, 91-106. [CrossRef]

16. Deaton, A. COVID-19 and Global Income Inequality. LSE Public Policy Rev. 2021, 1, 1. [CrossRef]

17. Ibragimova, Z.F.; Franz, M.V. Inequality of Opportunity in the Russian Federation: Measurement and Evaluation on Microdata. Appl. Econom. 2019, 54, 5-25. [CrossRef]

18. Brewer, M.; Wren-Lewis, L. Accounting for Changes in Income Inequality: Decomposition Analyses for the UK, 1978-2008. Oxf. Bull. Econ. Stat. 2015, 78, 289-322. [CrossRef]

19. Cowell, F.A.; Fiorio, C.V. Inequality decompositions-A reconciliation. J. Econ. Inequal. 2011, 9, 509-528. [CrossRef]

20. Fields, G.S. Accounting for income inequality and its change: A new method, with application to the distribution of earnings in the united states. In Worker Well-Being and Public Policy; Emerald Group Publishing Limited: Bingley, UK, 2004; Volume 22, pp. 1-38. [CrossRef]

21. Ravallion, M.; Atkinson, A.B.; Micklewright, J. Economic Transformation in Eastern Europe and the Distribution of Income. Economica 1994, 61, 253. [CrossRef]

22. Milanovic, B. Income, Inequality, and Poverty during the Transition from Planned to Market Economy; The World Bank (Regional and Sectoral Studies): Washington, DC, USA, 1998.

23. Commander, S.; Tolstopiatenko, A.; Yemtsov, R. Channels of redistribution: Inequality and poverty in the Russian transition. Econ. Transit. 1999, 7, 411-447. [CrossRef]

24. Dang, H.-A.H.; Lokshin, M.M.; Abanokova, K.; Bussolo, M. Welfare Dynamics and Inequality in the Russian Federation During 1994-2015. Eur. J. Dev. Res. 2019, 32, 812-846. [CrossRef] 
25. Lisina, A.; Van Kerm, P. Understanding Inequality and Poverty Trends in Russia. Proc. Special IARIW-HSE Conf. Experiences and Future Challenges in Measuring Income and Wealth in CIS Countries and Eastern Europe, Moscow. 2019. Available online: http:/ / ecineq.org/ecineq_paris19/papers_EcineqPSE/paper_322.pdf (accessed on 3 September 2020).

26. Gustafsson, B.; Shi, L.; Nivorozhkina, L. Why are household incomes more unequally distributed in China than in Russia? Camb. J. Econ. 2011, 35, 897-920. [CrossRef]

27. Murashov, Y.; Ratnikova, T. Under-reported income of Russian households. Russ. J. Econ. 2016, 2, 56-85. [CrossRef]

28. Shorrocks, A.F. Inequality Decomposition by Factor Components. Econometrica 1982, 50, 193. [CrossRef]

29. Shorrocks, A.F. Inequality Decomposition by Population Subgroups. Econometrica 1984, 52, 1369. [CrossRef]

30. Stark, O.; Taylor, J.E.; Yitzhaki, S. Remittances and Inequality. Econ. J. 1986, 96, 722. [CrossRef]

31. Lerman, R.I.; Yitzhaki, S. Income Inequality Effects by Income Source: A New Approach and Applications to the United States. Rev. Econ. Stat. 1985, 67, 151. [CrossRef]

32. Nivorozhkina, L. Hidden income of households: An empirical evidence. Terra Econ. 2016, 14, 42-53. [CrossRef]

33. López-Feldman, A. Decomposing Inequality and Obtaining Marginal Effects. Stata J. Promot. Commun. Stat. Stata 2006, 6, 106-111. [CrossRef]

34. Yitzhaki, S. Do we need a separate poverty measurement? Eur. J. Politi. Econ. 2002, 18, 61-85. [CrossRef]

35. Nivorozhkina, L.I.; Arzhenovskiy, S.V.; Safarova, L.A. Statistical estimation of the level of inequality and poverty of Russian households (an alternative approach based on the decomposition of the Gini index). Account. Stat. 2007, 2, 155-173. Available online: https: / / elibrary.ru/item.asp?id=11620883 (accessed on 1 October 2021).

36. RLMS-HSE. Available online: http:/ / www.cpc.unc.edu/projects/rlms (accessed on 1 September 2020).

37. Pissarides, C.A.; Weber, G. An expenditure-based estimate of Britain's black economy. J. Public Econ. 1989, 39, 17-32. [CrossRef]

38. Nivorozhkina, L.I.; Arzhenovskiy, S.V. Estimating of hidden household incomes: Aspect of the measurement period duration. Financ. Res. 2020, 3, 27-39. Available online: https:/ / finis.rsue.ru/2020_N3/2020-3.pdf (accessed on 20 September 2021).

39. Murashov, Y.V.; Ratnikova, T.A. Dynamics of unrecorded incomes of Russian households. Appl. Econom. 2017, 2, 30-54. Available online: http://pe.cemi.rssi.ru/pe_2017_46_030-054.pdf (accessed on 20 September 2021). 